\title{
DERECHOS SEXUALES Y DERECHOS REPRODUCTIVOS
}

\section{SEXUAL RIGHTS AND REPRODUCTIVE RIGHTS}

\author{
Enrique Guevara Ríos ${ }^{1 a}$
}

Los derechos humanos son derechos inherentes a todos los seres humanos: derecho a la vida y a la libertad, derecho a no estar sometido ni a esclavitud ni a torturas, derecho a la libertad de opinión y de expresión; derecho a la educación, a la salud, al trabajo, entre otros muchos.

Estos derechos corresponden a todas las personas, sin discriminación alguna: raza, sexo, nacionalidad, origen étnico, lengua, religión o cualquier otra condición¹.

Desde entonces, las Naciones Unidas han ido ampliando los derechos humanos para incluir normas específicas relacionadas con las mujeres, los niños, las personas con discapacidad, las minorías y otros grupos vulnerables, que ahora poseen derechos que los protegen frente a la discriminación que durante mucho tiempo ha sido común dentro de numerosas sociedades.

En 1968 se llevó a cabo la Conferencia sobre los Derechos Humanos de Teherán², donde se incluyó el derecho de las parejas para decidir libremente y bajo su responsabilidad el número y espaciamiento de los hijos.

La Conferencia Internacional sobre la Población y el Desarrollo (CIPD) ${ }^{3}$, se celebró bajo los auspicios de las Naciones Unidas, en El Cairo, Egipto, del 5 al 13 de septiembre de 1994; por primera vez, los derechos sexuales y reproductivos de la mujer se convirtieron en el elemento central del acuerdo internacional sobre población y desarrollo.

Los derechos sexuales ${ }^{4}$ comprenden el derecho básico de toda pareja y de toda persona de tener una vida sexual responsable, satisfactoria y segura; esto es, libre de enfermedad, lesiones, coerción o violencia, e independientemente de la situación reproductiva de cada uno. A tener acceso a una educación en sexualidad, que sea oportuna, integral, gradual, científica y con enfoque de género, y el respeto de las personas a su preferencia sexual; y a contar con información y servicios de prevención y tratamiento de las infecciones de transmisión sexual (ITS), incluyendo el virus de inmunodeficiencia humana VIH-SIDA.

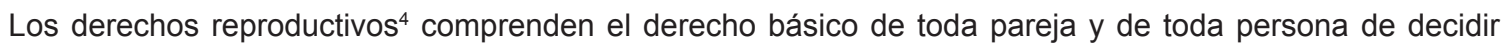
libre y responsablemente sobre el número, el espaciamiento y la oportunidad de tener hijos/as y de tener la información y los medios de hacerlo, así como acceder plenamente a los métodos para regular la fecundidad. Asimismo, comprenden contar con servicios de calidad para el cuidado de las gestantes y recibir atención de emergencia y contar con todos los insumos para garantizar la maternidad saludable y segura.

En el Perú los Derechos Sexuales y Reproductivos están protegidos como en el ámbito internacional: desde los derechos humanos que están reconocidos en la Constitución y también en diferentes normas que abordan los diferentes contenidos protegidos, como la Ley $N^{\circ} 28983$, Ley de Igualdad de Oportunidades entre mujeres y hombres ${ }^{5}$, la Ley Nº 26842, Ley General de Salud ${ }^{6}$, y la Resolución Ministerial Nº 668 -2004 /MINSA, que aprueba las Guías Nacionales de Atención Integral de la Salud Sexual y Reproductiva ${ }^{7}$, entre otras normas legales.

El 29 julio 2019, la Federación Internacional de Ginecología y Obstetricia hace un Illamado de "Atención a Proteger la Salud y Derechos Sexuales y Reproductivos"8, que incluye trabajar a favor de los derechos humanos y la salud, a disminuir la Mortalidad materna, prevenir el aborto inseguro y el Embarazo Adolescente,

\footnotetext{
Instituto Nacional Materno Perinatal. Lima, Perú.

a Médico Ginecólogo-Obstetra. Director del Instituto Nacional Materno Perinatal. Coordinador de Asistencia Técnica del Instituto de Salud Popular. Consultor de Pathfinder International. Profesor Ordinario de la Facultad de Medicina de la Universidad Nacional Mayor de San Marcos Lima-Perú.

Citar como: Guevara R. Derechos sexuales y derechos reproductivos. Rev Peru Investig Matern Perinat 2020; 9(1): 7-8 DOI https://doi.org/10.33421/inmp.2020183
} 
promover la anticoncepción, y prevenir la violencia contra las mujeres y el cáncer de cuello uterino.

En conclusión, los derechos sexuales y reproductivos garantizan la convivencia y la armonía sexual entre hombres y mujeres, entre adultos y menores, lográndose que la sexualidad y la reproducción se ejerzan con libertad y respetando la dignidad de las personas, permitiéndole al ser humano el disfrute de una sexualidad sana, responsable, segura y con el menor riesgo posible.

Financiamiento: Autofinanciado.

Conflicto de interés: El autor declara no tener algún conflicto de interés.

\section{REFERENCIAS BIBLIOGRÁFICAS}

1. Declaración Universal de los Derechos Humanos, Adoptada y proclamada por la Asamblea General en su resolución 217 A (III), de 10 de diciembre de 1948.
2. Proclamación de Teherán sobre los derechos humanos. Conferencia Internacional de Derechos Humanos. Teherán, 22 abril - 13 de mayo de 1968.

3. Conferencia Internacional sobre Población y Desarrollo. Naciones Unidas. El Cairo, Egipto. 5 - 13 setiembre 1994.

4. Távara L. Contribución de la revista peruana de ginecología y obstetricia al desarrollo de los derechos sexuales y reproductivos en Perú. Rev Peru Ginecol Obstet. 2017;63(3):393-408.

5. Ley $N^{\circ} 28983$, Ley de Igualdad de Oportunidades entre mujeres y hombres. Diario Oficial El Peruano. Lima, 16 marzo 2007

6. Ley $\mathrm{N}^{\circ} 26842$. Ley general de salud. Diario Oficial El Peruano. Lima, 15 JULIO 1997.

7. Ministerio de Salud. Guías Nacionales de Atención Integral de la Salud Sexual y Reproductiva. Lima, 2004. [350] p.; tab; ilus. ISNB 9972-851-13-3

8. Fuchtner C. Llamado de Atención a Proteger la Salud y Derechos Sexuales y Reproductivos. Federación Internacional de Obstetricia y Ginecología. 29 de julio de 2019. 